\title{
THE TREE OF LIFE IN JEWISH ICONOGRAPHY
}

\section{By Zofja Ameisenowa}

There is scarcely any symbol more ancient or more widely distributed than that of the cosmic Tree of Life with its promise of immortality and everlasting youth-a remarkable product of Semitic imagination in Western Asia. With the exception of the Cross of Christ, which is itself an embodiment of the Tree of Life in another form, no other symbol has been the subject of so much published research. The theme has proved so attractive that, apart from frequent excursions in works of a more general nature, twelve monographs have been devoted to it within the relatively short space of seventeen years. ${ }^{1}$

Wensinck's book, a very scholarly work based on the investigation of original sources, reveals the close connection between the cosmological Tree of Life and the solar bird (Eagle, Phoenix, Bennu, Simurgh). Wensinck describes the varying topography of the Tree of Life-the Tree of the Centre, of the East, West, South and North, and the Tree as guardian of the Gate of Heaven. He also considers the changing conception of the Tree as Tree of Life, Tree of Paradise, Haoma and Tree of all Seed, Tree of Day and of Night together with the parallel conception of it as the Tree of Hell or of Death in the literary and pictorial traditions of the peoples of the Near East between about I0oo B.C. and I000 A.D.

The two exhaustive works of Holmberg deal with the occurrence of the Tree of Life among the Ugro-Finnish peoples, who must have derived the conception from Central Asia or the Near East and retained it till very recent times. Gasiorowski's small but informative study, a résumé of a longer work, based on considerable knowledge of monuments, pursues the changes in form of the Tree of Life and what can be called a petrifaction rather than a development from the naturalistic palm-tree of the Babylonians with its symbolical significance down to the palm-ornament and candelabra of late antiquity.

The three works of Karutz, Lechler and Lauffer treat the theme from a general comparative point of view, with this difference that whereas Lauffer's very sound monograph is scientifically objective, Karutz' book has all the mystical obscurity of the anthroposophist Rudolf Steiner and cannot therefore be taken too seriously. Lechler's profusely illustrated article, which claims to be scientific, seems to be based on a misconception, for among a

1 A. J: Wensinck, "Tree and Bird as Cosmological Symbols in Western Asia," Verhandelingen der Kon. Akademie van Wet. te Amsterdam, Afd. Letterkunde, I92I. Uno Holmberg, "Der Baum des Lebens," Annales Acad. scient. Fennicae. Series B, Vol. XVI, No. 3, Helsingfors, 1922. U. Holmberg, "The Tree of Life," Mythology of all Races, IV, p. 352 , Boston, 1927. R. Karutz, Der Baum des Lebens, Stuttgart, I930. S. Gasiorowski, "Das Motiv des Lebensbaumes ... in der antiken Ornamentik," Bulletin de l'Acad. Polon. des Sciences, Cracow, 13.II.193o. Offprint. G. Lechler, "The Tree of Life in Indo-European and Islamic Cultures," Ars Islamica, 1937, pp. 369-416, pl. 148. O. Lauffer, "Schicksalsbaum und Lebensbaum im deutschen Glauben und Brauch," Zeitschrift f. Volkskunde N. F., Vol. 7, 1937, pp. 216-230.
L. Walk, "Lebensbaum-Kreuzesbaum," Kirchenkunst, Vol. II, 1938, pp. 53-57.

Strzygowski also quotes $\mathrm{K}$. von Spiess, Monatsbaum, Jahresbaum, Lebensbaum, Weltenbaum, but gives no further details. A. Parrot, Syria, IV, 1937, mentions a very exhaustive study : H. Danthine, Le palmier-dattier et les arbres sacrés dans l'iconographie de l'Asie occidentale ancienne, Paris, I937, which has in the meantime been published, but has not been consulted for this essay. After the present work had reached its final form three appeared N. Perrot, Les représentations de l'arbre sacré sur les monuments de Mésopotamie et d'Elam, Paris, $193^{8}$ and Bauerreis, Der Lebensbaum und seine Verwendung in Liturgie, Kunst und Brauchtum des Abendlandes, Munich, 1939. 
great mass of objects dealt with only a very few can be regarded as genuine representations of the Tree of Life. Moreover, the literary and plastic material included shows such confusion of epochs and countries and peoples, of heterogeneous symbols on the one hand and entirely non-symbolic ornament on the other, especially in prehistoric examples or in very late products of popular art, that the methods and conclusions of the author naturally arouse suspicion. Lechler tries to show the existence of the Tree of Life in prehistoric Northern monuments, and finds it where there is obviously no symbolical or religious tendency at all. Our doubts are confirmed by Otto Lauffer's essay which appeared at the same time as Lechler's work. Lauffer, supported by the statements of A. Meissner, the greatest living German ethnologist, shows that the Tree of Life in as far as it appears on Germanic monuments, is always a late borrowing from Oriental Semitic conceptions and myths, chiefly from the account given in Genesis II, 9; he further shows that the peoples of the North never knew the Tree of Life with its message of immortality, because they, and even their gods, completely lacked the concept and attribute of immortality; the gods of the Germanic North perish in the last battle (Götterdämmerung). Lauffer draws a sharp distinction between the Iranian and Semitic conception of the paradisiac Tree of Life found among the peoples of India, the Iranians, Assyrians and Hebrews on the one hand, and the Tree of Fate associated with the individual destiny of mortal men-the tree which is even in our own time often planted at the birth of a child in Central and Eastern Europe. He categorically denies the identity of the World-ash Yggdrasil and the Tree of Life, and so brings clarity and order into the confusion of ideas.

On the basis of this literature, of other works which will be mentioned later, and with the help of a considerable amount of original material, we may say that the Tree of Life which was a religious and mythical symbol of the first importance in the civilization of antiquity in the Near East, lost its significance in late Graeco-Roman civilization and degenerated into a mere palm or candelabra ornament. But in late antiquity it was revived as a symbol in two centres geographically and ideologically distinct : in early Christianity and in the Sassanian empire among the inheritors of Iranian civilization. ${ }^{1}$ Eventually it was expelled by the Christian cross, or rather it assumed this form among the Christians, and among the peoples of Islam it degenerated into ornament. Only rarely do we find in the products of Islamic craftsmanship any suggestion of the original nature of the Tree of Life as the expression of mythical and religious ideas, as for instance, in a miniature in Calcutta dating from Mogul times or in a few very early rugs. ${ }^{2}$

By what process this came about and by what means the myth of the Tree of Life with its symbols from the Near East survived the passing of antique civilization and found its way into Christendom and the early mediaeval world is a question to which only a few scholars have found any clear answer; otherwise we have to fall back upon fantastic hypotheses, such as that of Strzygowski on the direct transference of the Tree of Life from the Iranians to the early Christians. ${ }^{3}$ This assumption is untenable because there are no Iranian pictorial representations dating from the earliest days of Christianity before the time of Constantine. Moreover there is no direct connection between the purely ornamental palm and candelabra motives

1 C. Orbeli and J. Tréver, L'orfèvrerie sassanide, Moscow-Leningrad, 1935, pls. 32, $48,72$.

2 J. Strzygowski, Asiatische Miniaturenmalerei, 1933, pls. 69, 195. F. Sarre and
H. Trenkwald, Altorientalische Teppiche, 1926, pls. $35,4 \mathrm{I}$.

3 J. Strzygowski, , Spuren indogermanischen Glaubens in der bildenden Kunst, Heidelberg, 1936, pp. I I 7-121. 
of Græco-Roman antiquity and the symbolical representations in early Christian paintings and on the sarcophagi of Ravenna. The Tree of Life as a symbol and in particular as an eschatological symbol of paradise must therefore have reached early Christendom in a different way-doubtless through Jewish sepulchral art of late Hellenistic times.

All the writers who have ever in any way touched upon the problem of the Tree of Life have mentioned the passage in Genesis II, 9, and have emphasised the survival of the legend of the Tree of Life in later Jewish literature. But they have never faced the question whether the Jews possessed any representation of the Tree of Life or whether the ancient and long-lived tradition in Jewish literature had any counterpart in the plastic art of the Jews. Misled by the supposed absolute prohibition of the pictorial arts by the Jews and their complete unproductiveness in this field, Wensinck and others have quoted a large number of tales concerning the fabulous tree from talmudic, cabbalistic and late apocryphal sources, without citing any corresponding pictorial version. And yet such a tradition does exist. It is the purpose of the present article to fill this lacuna and to show how the symbol arose among the Jewish people in prehistoric times, how it acquired its outer form and symbolic content through contact with other civilizations, how it passed through a succession of changes, survived for thousands of years and maintained almost down to the present day its full religious and symbolic meaning. ${ }^{1}$

\section{II}

When the patriarchs first came to Canaan they found the cult of the sacred stake on the hill (ashera). The stake was probably originally a living tree, which became in the course of time a tree-stump, inhabited by the goddess of fertility, Asira. There is such frequent mention of Asheroth in the second Book of Kings ${ }^{2}$ that the compiler of Deuteronomy and the prophets of the days before the Exile found good reason for violent opposition to this cult and for a long time were unable to stamp it out. ${ }^{3}$ But the patriarchs brought with them from their original home in southern Mesopotamia about the beginning of the second millennium B.C. the legend of the cosmic Tree of the World and of Life; and, if Dhorme's ${ }^{4}$ views are well-founded, also the conception of the Tree of Truth and of Knowledge,

1 This theme is approached from various angles in the work of R. Wischnitzer, Gestalten und Symbole jüdischer Kunst, Berlin, 1935 passim, but in view of the importance of the subject and the emergence of hitherto unnoticed monuments which have given rise to many urgent problems, it seems essential to deal with the subject again.

I wish to express my warmest thanks to all those who have assisted me in the preparation of this article; especially to Dr. D. Künstlinger of Cracow for the translation of texts from the Talmud and the Cabbala, and also to the Directors of the Manuscript Department of the Bibliothèque
Nationale in Paris, the British Museum, the Stadtbibliothek in Frankfort, the Library of the Jewish Theological Seminar in Breslau for their readiness to supply me with information and for permission to publish the manuscripts which are here reproduced for the first time.

${ }^{2}$ Deut. VII, 5, II Kings, xviii, 4-xxi, 7. Nilsen Ditlef, "Die altsemitische Muttergöttin", $Z D M G$, vol. 92, 1938, pp. 505-551.

${ }^{3} \mathrm{~J}$. Frazer, Folk-Lore in the Old Testament, I9I8, III, p. 64.

${ }^{4} \mathrm{P}$. Dhorme, "L'arbre de vérité et l'arbre de la vie," Revue biblique, 1907, pp. 271274 . 
which was later inserted into Genesis by the Jahvistic scribe of the ninth century. The conception of the mighty tree which touches the sky with its topmost branches or itself forms the firmament, the tree in which the sun dwells and the fruits of which give immortality, is founded on the prehistoric Iranian religion, which combines the Indo-Aryan and Semitic myths of the Near East; it is common to all the pe sples of Asia. The Chaldæans knew of the giant tree which grew in Eridu and was guarded by the sun-bird. ${ }^{1}$ The oldest representations of the Tree of Life come from the region of the Euphrates and Tigris-the cylinders recently discovered in Ur representing the Tree of Life with a goat on each side, which Legrain $^{2}$ assigns to the period of the first dynasty, ca. 2850 B.C.; a thousand years later the Tree of Life appears in its classical form as a fruit-laden date-palm, accompanied by two astral symbols, the sun-bird and the winged disc of the sun on the seal which is now preserved in New York. ${ }^{3}$

And so in Canaan there developed the myth of the Tree of Life so often mentioned in varying contexts in canonical books and apocryphal writings, a myth with a two-fold origin: on the one hand the local Canaanite cult of Asheroth, the ineradicable worship of the tree which has left its traces in the Genesis accounts of the sacred Terebinth in Mamra where Abraham entertained the three angels, or the tree in Sichem under which Jacob buried the teraphim-and on the other the popular belief in the cosmic tree with its fruits of immortality, which came from Mesopotamia. The oldest representation preserved from the days of ancient Israel is probably of not much later date than the account in Genesis II, 9 of "the Tree of Life" in the midst of the garden. On the front of a clay-vessel, the so-called incense-altar from Ta'anak near Megiddo in Northern Palestine, dating from about the eighth Century B.C., there is a relief showing the Tree of Life between two leaping ibices. ${ }^{4}$ The Tree of Life is here represented schematically without any indication of species, after the fashion of many Assyrian seals. ${ }^{5}$

From this period down to about the first century B.C. there is a long interval in the series of monuments which can only be filled by literary references. But these literary data are very informative and show the important part which the myth of the Tree of Life played among the Jews; originating in the popular religion, which absorbed every mythological element, it soon made its way among the prophets and learned men of Israel, and became the most popular motive of allegory and prophetic vision. ${ }^{6}$ The most important passages in which is occurs will help us to understand the meaning of the monuments. Quite early in prophetic writings, especially in the books of Ezekiel and Zechariah, the Psalms and

${ }^{1}$ P. Dhorme, op. cit., loc. cit. "In Eridu there grows a dark palm-tree; it sprouted forth in a pure place, it shines like the Uknu stone, it points to the sea." IV. Rawl. I5a.

2 Ur Excavations III. Archaic Seal Impressions, London, 1936. Pls. I, 37, IX, 197, X, 213.

3 W. H. Ward, Cylinders and other ancient oriental Seals in the Library of 7. P. Morgan, I 909 , No. I59.
4 A. Jeremias, Das Alte Testament im Lichte des alten Orients, 1930, fig. I 12.

${ }^{5}$ Ward, op. cit., No. 700.

6 W. Staerk, "Hat sich der Paradiesesmythos Gen. 2, 9 in parsistischer Tradition erhalten?" In : Werden und Wesen des Alten Testaments, Berlin, r936, pp. 225235 . 
the Proverbs, the Tree of Life is associated with the Judgment, with life after death, the Messiah and the new Jerusalem. The primeval paradisiac Tree of Life gives place to the Tree of Life of the Latter Days, the food of the blessed with promise of life everlasting and eternal youth. This is and remains the most essential and the most important addition made apparently by the Jews to the ancient myth of the cosmic tree from the Near East; they joined it inseparably to the Messianic hope of a return to the early bliss of paradise. This must be regarded rather as a parallel development on the common foundation of the old popular religion of Mesopotamia than as the result of influence from the Parsee writings, which were edited probably at a later date. (Bundehesh edited for the first time in the Sassanian epoch).

The phrase in Proverbs XI,30 "The fruit of the righteous is a tree of life" is especially characteristic because of its eschatological meaning. And the simile in the Books of Psalms I, 3 , "And he shall be like a tree planted by the rivers of water" must refer to the Tree of Life which stands over the sources of the rivers of Paradise and the water of life. Gressmann ${ }^{1}$ has pointed out that the prophets are particularly fond of applying the allegory of the cosmic tree to the kings of this world-like Pharaoh or Nebuchadnezzar (Daniel IV, I0-I6, Ezekiel XXXI, 3-9), in order to emphasise the idea of hybris and foretell sudden fall from power. On the other hand we may note that the children of Israel are also readily identified with the Tree of Life. Isaiah LXV, 22 says: "for as the days of a tree shall be the days of my people." It is significant that the translators of the Targum and Septuagint and the author of a commentary on the Pentateuch, R. Bechai, amend the first part of this passage to "like a tree of life." And the reference is the same in Isaiah V, 7: "for the vineyard of the Lord of hosts is the house of Israel." The deep impression made on the minds of the captives by the magnificent buildings which they saw in their exile adorned by Trees of Life and with cherubim is revealed in Ezekiel's vision of the Temple (XLI, I7-r8), where a whole palm-forest of trees of Life is conjured up, guarded by cherubs in half-human, half-animal form. A passage in Ezekiel (XLVII, I2) is of importance for our later investigation of mediaeval pictorial tradition; the prophet foretells the planting of the Tree of Life by the southern wall of the Messianic temple of the future; "over the parting of the living water." But the most abundant references to the Tree of Life are to be found in the apocalyptic and eschatological apocryphical books of the Old Testament which appeared over a space of two hundred and fifty years between the middle of the second century B.C. and the end of the first century A.D. The meditations and hopes of these generations are centred on the coming of the Paraclete. In these poetic visions in which Babylonian and Persian elements are mingled with Jewish and hellenistic ptolomaic Egyptian, the myth of the Tree of Life is endowed with new life and colour; it is enriched in a variety of ways and many old traditions find their reflection in it. Thus in the Sybilline Oracles ${ }^{2}$ the cosmological character of the Tree of Life is clearly described, and special reference is made to its character as a bearer of light;

${ }^{1}$ Der Messias, 1929, pp. 264-265.

${ }^{2}$ Proem. 84. Translated by E. Kautzsch, gen, 1900.

Die Apokryphen des Alten Testaments, Tübingen, rgoo. 
"the worshippers of the true and eternal god shall dwell in the green garden of paradise and shall eat of the sweet bread from the starry heaven." Here the firmament is equated to the Tree of life. It is at this time that the varying morphology of the Tree of Life becomes crystallised, the effects of which appear in the representations of a later date. According to Enoch ${ }^{1}$ the Tree of Life grows on the seventh hill of paradise where the throne of God will stand at the Last Judgment. Its blossoms are more fragrant than any perfume, its leaves and its stem never wither, but its fruits are the fruits of the palm-tree; and then, apparently referring to Ezekiel XLVII: "the fruit of it shall give life to the chosen ones and it shall be planted to give food in the sacred place beside the house of God, the King of Eternity . . . then they shall rejoice exceedingly and enter into the holy place." The apocalyptic writers think of the Tree of Life as an olive-tree (Vita Adae 36 and II Enoch VIII, 5); beside the cosmic tree stands the olive-tree, whose oil flows unceasingly and is an ointment for the blessed giving them eternal life. ${ }^{2}$

The Testamentum Levi 3, I8 (trans. Kautzsch, Vol. II, p. 47I) explicitly identifies the Tree of Life of the earthly paradise with that of the Messianic text: "the heavens shall open. He himself [the priest-king] shall open the doors of paradise and shall put aside the sword which threatens Adam and shall give the holy ones to eat of the wood of life and the spirit of holiness shall be in them."

When Philo, ${ }^{3}$ influenced probably by references to the golden vine in the temple of Herod, ${ }^{4}$ describes the world-tree as a giant vine with grapes as big as a man, the uncertain distinction between the original cosmic tree and the eschatological Tree of Life disappears; this often happens in works of these authors just as it had happened in the prophetic and apocalyptic writings. ${ }^{5}$

These literary records of visions of the Tree of Life have their counterpart in Jewish pictorial representations as early as the first century B.C.- on sepulchral monuments or on monuments which have obviously some connection with eschatological and apocalyptic ideas. The oldest of this group is a little-known Jewish ossuary of Palestinian origin ( $\mathrm{Pl}$. 55a), probably of the first century B.C. which was in Baron Ustinow's collection in Jerusalem in $1907 .{ }^{6}$ It is a box of white limestone, and a bas-relief on the front represents a conventional fruit-bearing palm-tree between two twelve-pointed stars. We have here a representation of the Tree of Life described so often in contemporary apocalyptic writings - a fact which escaped the attention of the Abbé Vincent but was recognised by Watzinger.?

${ }^{1}$ Kautsch, op. cit., Vol. I, Chaps. 24-25, pp. 253-254.

海 2 "Arbor misericordiae Dei, de qua currit oleum vitae" L. Troje, "Adam und Zoe," Sitzungsberichte der Heidelb. Akad. I916, Hist. phil. Klasse. Heft 17, pp. 83-89.

${ }^{3}$ De plant., Lib. II, cap. I. Ed. CohnWendland, vol. II, p. I31, par. 2-4.

4 Josephus, Bel. Fud. 5,4; confirmed by Tacitus, Hist. 5,5. Cf. R. Eisler, Welten- mantel und Himmelszelt, Munich, I910, p. 575.

5 A. Wünsche, "Die Sagen vom Lebensbaum und Lebenswasser," Ex Oriente lux, Heft 2-3, Leipzig, r 903 . P. Volz, Jüdische Eschatologie von Daniel bis Akiba, Tübingen, I 903 , p. $365 \mathrm{ff}$.

${ }_{6} \mathrm{H}$. Vincent, "Ossuaires juifs," Rev. bibl., 1907, p. I Io.

${ }_{7} \mathrm{H}$. Kohl and K. Watzinger, Antike Synagogen in Galiläa, 1916, p. 187. 
The two stars on either side are therefore not merely ornamental. The very frequent occurrence of star-motives in Jewish sepulchres and especially on ossuaries recalls the Jewish ideas concerning the incarnation of the souls of the righteous and their sojourn among the stars: "the godly shall shine like the stars in heaven." 1

There is no lack of representations of the Tree of Life on earthenware lamps found in Palestinian and Roman graves dating from the first centuries A.D. ${ }^{2}$ as well as on tablets in Jewish catacombs. Some of these were published recently by Frey. ${ }^{3}$ On one of the tablets, from the catacomb of the Via Appia (the construction of which was begun in the first century) the Tree of Life is seen between two birds; on another, apart from the almost inevitable candlestick, a vase and a dove, we see the Tree again with a bird on it pecking, which probably represents the soul of the departed Esther. But we are not solely dependent for our evidence on these somewhat mechanical products; they have been cited in order to show the popularity of the motive among the widest circles of the Jewish people in late antiquity. There are better pictorial representations. Unfortunately we do not know what the paintings were like which came from a tomb in Sarepta and were described by Renan. ${ }^{4}$ But we know that they contained a representation of red palm-trees between sun and moon-a composition which corresponds to the ossuary in the Ustinow Collection. So we may assume that the palms in the four corners of a hypogæum of the first century Jewish catacomb in the Via Appia were meant to represent Trees of Life. ${ }^{5}$ The same is true of a badly damaged marble sarcophagus from the second century catacomb mentioned above now in the Kaiser Friedrich Museum in Berlin. ${ }^{6}$ On each side of the sevenbranched candlestick stand two palm-trees, and between these, very carefully chiselled, Ethrog and Lulab, the Schofar, Aaron's sprouting staff and two disc-shaped objects which have not yet been interpreted. It is only a short step from this sarcophagus, which is certainly not an exceptional case, to the early Christian sarcophagi, particularly those made in Ravenna under Syro-Palestinian influence, in which the place of the candlestick is taken by the figure of Christ, by the monogram of Christ or by the Lamb, between the palm-trees which are generally recognised as Trees of Life. ${ }^{7}$ Thus Watzinger is right when he draws the obvious conclusion that at this point Christian art links up, not with pagan antiquity, as von Sybel thought, but directly with Eastern Jewish art. ${ }^{8}$

One of the most interesting monuments from the point of view of religious and cultural history, although it is of little artistic significance, is the fragment of a relief probably from a transenna of imperial times, found in the Jewish catacomb of the Palazzolo Acride (Acrae) now at the Museum at Syracuse

1 W. Bousset, Die Religion des Judentums im neutestamentlichen Zeitalter, Berlin, I906, pp. 3r8-3r9.

${ }_{2}$ Cf. reproductions in Füdisches Lexikon, Vol. III, col. II 4 .

${ }^{3}$ J. B. Frey, Corpus inscriptionum iudaicarum, Vol. I, Rome, 1936, nos. 144 and 306.

${ }^{4}$ E. Renan, Mission en Phénicie, p. 664. F. Cumont, Les fouilles de Doura Europos, Paris, 1926.
Appendix, "Les peintures antiques de Syrie." ${ }^{5}$ J. B. Frey, op. cit., p. CXX, fig. ibid.

${ }^{6}$ Kohl-Watzinger, op. cit., pp. I86-187. A good reproduction in Lietzmann-Beyer, Die jüdische Katakombe der Villa Torlonia, Berlin, I930, pl. 28.

7 O. Wulff, Altchristliche und byz. Kunst, 1914, pls. 173, 176, 179, and 180 .

8 Op. cit., p. 187. 


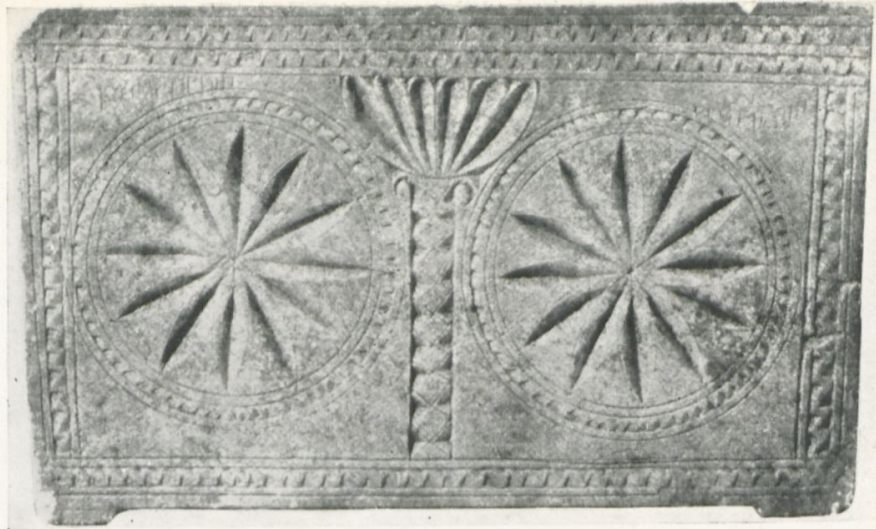

a-Jewish Ossuary. Ist century B.C. (?). Formerly Jerusalem, Ustinow Coll. $(p .33 \mathrm{I})$

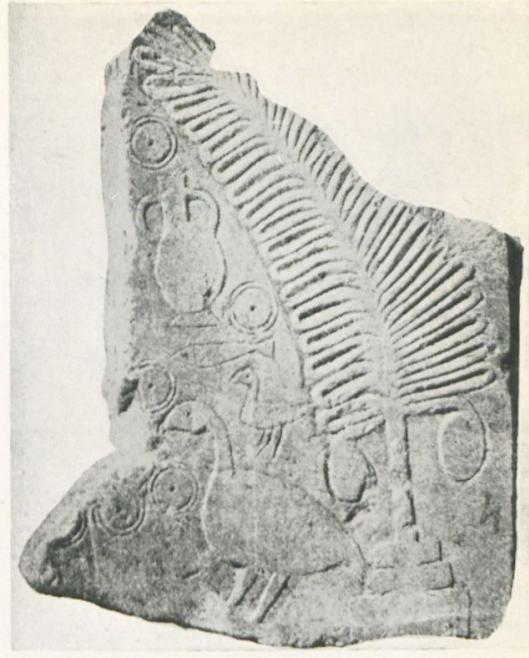

b-Fragment from the Jewish Catacomb lat Acrae. Syracuse, Museum ( $p$. 333)

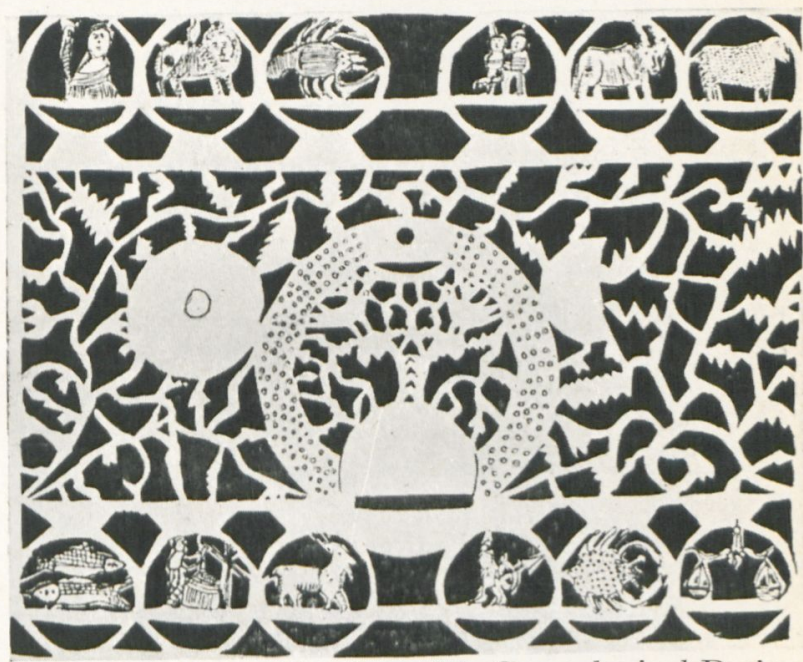

d-Jewish Paper Cutting with Cosmological Design. Modern. (p. 344)

c-Tomb at Zockiew
Poland, I $770(p .344)$

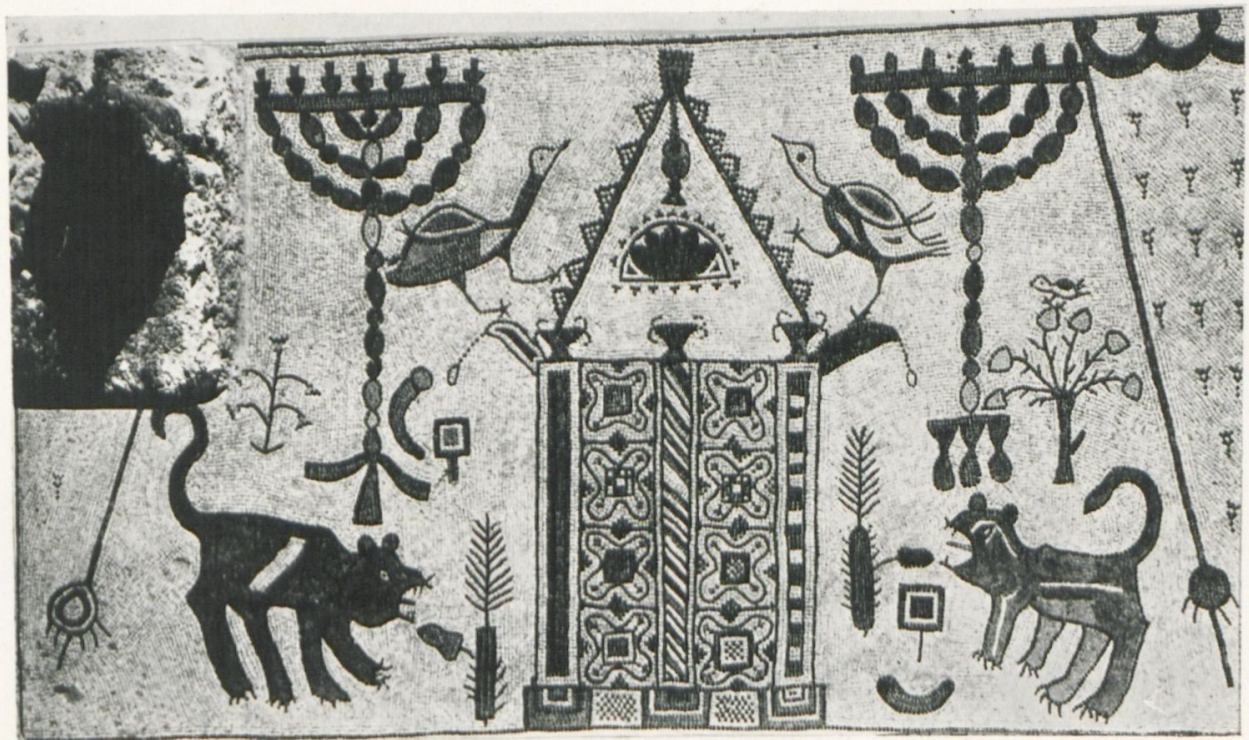

e-Beth Alpha, Synagogue. Mosaic, 6th century A.D. ( $p .343 \mathrm{f}$. 

(Pl. 55b). A reproduction of it was first published by Orsi; it was described cursorily by J. B. Frey but his interpretation was inadequate. ${ }^{1}$ Dölger regards the Acrae relief as a monument of the "Syro-Phoenician-Punic cult of Baal-Astarte in Sicily" - a fantastic assumption from the point of view of religious history and of the history of art. ${ }^{2}$

The relief is in a very bad state of preservation; probably half or even two-thirds of it must have been lost. But what remains indicates a very wide combination of eschatological motives. From left to right we have the date-palm, laden with heavy fruit, growing not directly out of the ground, but rising above a mound formed by three blocks of stone which diminish in size from the lowest to the highest; it may therefore be regarded as the Tree of Life of the Messianic paradise. For this stony structure is simply the centre of the world, the navel-stone of the earth held by the Greeks to be at Delphi but by the Jews in the Temple at Jerusalem. It is the legendary stone called Shettija (the foundation). Referring to Ezekiel V, 5: "This is Jerusalem : I have set it in the midst of the nations and countries that are round about her" - the Midrash Tanchuma of Kedoshim continues: "as the navel is in the middle of man so is the land of Israel in the middle of the world."'3 The much older Jewish tradition, cited in the Midrash, holds the stone Shettija, the foundation stone at the creation of the world, to be the one fixed point in the universe. Beneath this stone the waters of the universe are stored - the flood which God made to flow back into the depths and sealed up with the stone Shettija. Jerusalem, that is the Mount of the Temple, was regarded not only by the Jews, but by the Christians and the Mohammedans also as the centre of the world. ${ }^{4}$ The connection between the Tree of Life and the centre of the world is alluded to in Psalm I, 3, where we read of the Tree of Life which was planted by the streams of water. But since on the Day of Judgment the Tree of Life is to be planted in the middle of the universe by the southern wall of the new temple (Ezekiel XLVII, I2), it is clear why the Jewish mason who chiselled the Acrae relief at the beginning of the Christian era represented the date-palm, which yields the gift of everlasting life, as growing over the navel stone of the earth, in the temple of Jerusalem. Another passage from the Talmud (b. Joma Mishna 5, 3) narrates that the Shettija stone is "higher than the earth by three fingers"; it is probably for this reason that it is composed of three steps on the Acrae relief. This is not the only detail which shows the mason's familiarity with Jewish haggadistic tradition. On the left, beside the Tree of Life, stands a very fat goose. This is not introduced, as Orsi thought, because the goose is a favourite dish of the Jews. The meaning of it becomes clear only when it is put side by side with

${ }^{1}$ P. Orsi, "Nuovi ipogei di sette cristiane e giudaiche ai Cappucini in Siracusa, con aggiunti di qualche monumento ebraico della regione," Roem. Quartalschrift, I900, pp. 206207. J. B. Frey, Corpus Inscriptionum Iud., I, no. 653 a.

2 F. Dölger, Ichthys, Vol. I, Rome, I9ıо, p. $44^{2}$, fig. 79 .
${ }^{3}$ W. H. Roscher, Omphalos, Leipzig, I913, pp. 24-29. W. H. Roscher, Neue Omphalosstudien, Leipzig, I9I5, pp. I 5 and 74 . D. Feuchtwang, "Das Wasseropfer und die damit verbundenen Zeremonien," $M G W \mathcal{J}$ I9IO/II, pp. 535,7 I 3 ff.

${ }^{4}$ W. H. Roscher, op. cit., p. 27. 
the other foods promised to the chosen ones in after-life-the fruits of the Tree of Life, the flesh of the Leviathan (which appears as an insignificant little fish) the Amphora of wine, which was kept for the godly since the creation of the world, and the Behemoth, which was probably represented on the lost part of the monument. From the Baba Bathra (fol. 73b, col. 2) in which the Feast of the Blessed is described, we learn that Rabba, the grandson of $\mathrm{R}$. Channa, once saw geese in a wilderness, whose feathers fell out because they were so fat. He asked the geese : "Shall we have a portion of you in the world to come when the Messiah manifests himself?" And the geese gave answer, one by flapping its wings, another by a movement of the head and a third by raising its foot, as if they meant : this is your portion in the world to come. The small bird above the goose is probably the dove, the symbol for the happy soul of the deceased.

The fifth century mosaic floor from the synagogue of Hamman Lif (Naro) near Carthage, part of which is in the Musée del Bardo in Tunis and part in the Brooklyn Museum, presents a surprisingly analogous case from the iconographic point of view and is of considerably higher artistic merit. ${ }^{1}$ The central part of this mosaic, now in Tunis, is divided into two rectangular panels, between which the founder's inscription is written. A paradisiac landscape is represented beneath. Between two date-palms, above the spring of the Water of Life, peacocks are hovering, the symbols of immortality. The duplication of the tree-motive for the sake of symmetry is not unusual; it frequently occurs on early Christian sarcophagi. It need not be assumed that the second tree is the fatal Tree of Knowledge. For there is no source which mentions the recurrence of this Tree in the latter days; in the Middle Ages it is identified with the Tree of Death or of Hell. Most of the left half of the upper panel has been destroyed. But from what remains on the right we may assume that in the light of a colossal sun-wheel (the heavenly bodies are supposed to shine seven times more brightly in Paradise) there was a representation of the beasts which were promised as food to the righteous in the life to come : the giant fish Leviathan and its mate, the ox Behemoth, of which only the horned head remains, and the fat geese known to us on the Acrae relief - a fact which has hitherto escaped notice.

These monuments which range from the first century B.C. to the fifth century A.D., have been chosen as examples and lay no claim to completeness. But from them we may assume that the association of the Tree of Life with the Messianic paradise of the future, established in the times of the prophets, acquired plastic form among the Jews in the Hellenistic age. Further, that the Tree of Life, which at this same time in late Græco-Roman art was used for purely decorative purposes as a palmette or candelabra ornament, ${ }^{2}$ came to be applied in Jewish sepulchres as a religious eschatological symbol, and that in imperial times new haggadistic legendary motives found their way into the Jewish eschatological representations of Paradise. Finally we may assume that early Christianity in its

${ }^{1}$ R. Wischnitzer, Gestalten und Symbole der jüdischen Kunst, pp. 12 I-I 22, pl. $3^{6 .}$ F. M. Biebel, "The Mosaics of Hamman
Lif,'” Art Bulletin, 1936, pp. 541-551 (with bibliography for older relevant literature).

${ }^{2}$ Cf. Gasiorowski, op. cit., p. 9. 
representations of Trees of Life on sarcophagi turned not to the antique classical or even Persian tradition, but to the Jewish, just as the early Christian written tradition in these matters is dependent upon the Jewish. ${ }^{1}$

It must be noted that in almost all mythologies the Tree of Life is associated with light because the whole of organic life is d spendent upon the light of the sun. In the oldest Babylonian myths the sun-bird has its nest on the cosmic tree. ${ }^{2}$ The Persian Tree of Life is frequently addressed as the Tree of the Eagle, the Sun-Bird. ${ }^{3}$ The Egyptian city of Heliopolis had its own cult of the Sun-Tree which was associated with the Sun-Bird Bennu (the Phoenix). But the identification of the Tree of Life with the seven-branched candlestick, which, as the account in Exodus XXV clearly proves, was derived from a plant-form, is specifically Jewish. Even Philo ${ }^{4}$ knew that the seven-branched candlestick was also a symbol for the sun and the planets. This was proved definitely by Gunkel in I895 in his lucid interpretation of the Vision of Zechariah IV, I-6, I0-1 $3 .^{5}$

There is no lack of monuments dating from various epochs, on which the candlestick takes the place of the Tree of Life or is shown in conjunction with it. Nowhere, however, is the connection between these two religious symbols clearer than on a relief in the synagogue at Capernaum. Here we have a candlestick with, it is true, only five branches, and above it a palm-leaf ornament which together with the central branch or the Menorah forms the conventional palm-tree and is organically joined to the candlestick. ${ }^{6}$ The connection of the candlestick with the Tree of Life is retained in the later periods, and on many Jewish sepulchres of the baroque period we can see both these symbols either joined together or one above the other.

\section{III}

In the troublous times of the Jewish dispersion between the seventh and the twelfth centuries a strict orthodox iconoclasm prevails. Things which seemed in the earlier centuries quite harmless from the religious standpoint are now felt to be contrary to the law and abjured. Many monuments fall a prey to this iconoclastic zeal : we have evidence in the synagogues of Palestine, which have been more and more frequently excavated, and where mosaics and bits of architecture with figurative designs appear to have been intentionally destroyed. We possess no representations of the Tree of Life dating from these centuries, and so we must again have recourse to the literary sources, the Midrashes and the Zohar, in which the Tree of Life forms the centre of a multitude of legends and is adorned with a thousand fabulous details. Imagination in the Midrashes excels itself in numerical exaggeration of the size of the Tree. The oldest of these references is probably the description in the tractate Jer. Berachoth $2 \mathrm{c}$, a commentary on

1 Rev. XXI, Io and XXII, I.

${ }^{2}$ Wensinck, op. cit.

${ }^{3}$ U. Holmberg, Der Lebensbaum, p. 65.

4 Philo, Quis rer. div. haer. Ed. CohnWendland, vol. III, p. 22.

${ }^{5}$ H. Gunkel, Schöpfung und Chaos in Urzeit und Endzeit, Göttingen, 1895, p. 127.
H. Gressmann, Der Messias, I929, pp. 264265. R. Wischnitzer, op. cit., r935, p. 67 f., supplements Gunkel's statements.

${ }^{6}$ H. Rosenau, "Où classer la synagogue de Capernaum," Revue d'hist. et de phil. relig., Strasbourg, 1937, p. 288. 
Genesis II, 9, which we find frequently repeated. According to this tradition the circumference of the trunk takes five hundred years to encompass. The later Pesikta Zutrata to Gen. II, $9^{1}$ repeats the idea so commonly expressed in apocalyptic writings, that the Tree of Life was created so that the pious after death might eat of its fruits and enjoy everlasting life. There is a faint echo of old cosmological tradition in the Perek gan ha-hajjim, ${ }^{2}$ according to which the dimension of the Tree of Life corresponds to the dimension of the whole world, and its fruits which never fade are the fruits of all earthly plants, like those of the Gaokerena in the Bundehesh of the Parsees. ${ }^{3}$ The most interesting passage, however, is to be found in the Midrash Konen, ${ }^{4}$ which combines elements of diverse origin. "In the east of Paradise stands a third house, built of gold and silver and all precious stones and pearls." (In all the eastern mythologies these mean the sun, the moon and the stars). All the good things of heaven and of earth are stored in this place. Here are found all the different kinds of fruit and balms and perfumes. In the midst of it is the Tree of Life, as we are told in Genesis II, 9, and the height of the Tree is a journey of five hundred days. In its shade Abraham and Isaac and Jacob are seated together with the twelve tribes which departed from Israel and were disseminated in the wilderness. The chief among them are Moses and Aaron, who teach them the Law. Here also are David and Solomon, with their regal crowns. "And from the Tree of Life rise and descend the souls of the righteous in Paradise, like a man mounting or descending a ladder. The Tree of Life is planted above the source of the living waters . . .."

The most remarkable feature in this passage is the plastic description of the Tree of Life as a dwelling-place for the souls of the departed and as a place where they disport themselves. This description must go back to ancient Egyptian conceptions, which came to the Jews by way of Alexandria, as we can see from a representation of the Tree of Souls in a papyrus now preserved in Berlin. ${ }^{5}$

Many scholars, including Grunwald, ${ }^{6}$ state that the Midrash Rabba to Genesis II, 9, regards the Tree of Life as a palm-tree, a vine, ethrog, fig-tree and even as wheat. But this is not the case. All these plants are associated with the Tree of Knowledge, treated extensively by Luise Troje ${ }^{7}$ in the work quoted above. The Zohar, ${ }^{8}$ following the usual practice, describes the Tree of Life as a Tree of Light, which encompasses all living things. "The light of the Tree of Life with its radiance gives everlasting life to all creatures and endures to all eternity. No wickedness shall dwell there." In another passage, Zohar I, 35, the world-tree, branching in twelve directions, is called the source of the waters, which quicken all creation. Its root is

1 Ed. Buber.

2 Beth-ha-Midrash, Ed. Jellinek, V, 47.

${ }^{3}$ F. Windischmann, Zoroastrische Studien, I863, caps. IX, XVII, XVIII.

4 Beth-ha-Midrash, Ed. Jellinek, VI, 28.

${ }^{5} \mathrm{H}$. Gressmann, Altorientalische Bilder zum Alten Testament, 1927, p. 76, fig. 246. Without seeing the original, I cannot say whether the "tree with some birds on it," in the Farhi Bible, now in the possession of D. Sassoon in London, described in a letter from the owner, is a Tree of Souls or of Life.

6 Füd. Lex., Vol. III, col. 999-1000.

7 L. Troje, Adam und Zoe, pp. 9-1o. Berachoth 4oa, Midrash Rabba to Genesis XV, 7, Sanhedrin 7oa.

${ }^{8}$ II, fol. 2r, II, fols. 58-59, ed. Mantua. 
En Sof, and the Sefirot its stem, its branches, leaves and blossoms. Hence is derived the design of the tree which occurs so often in cabbalistic writings. Some similar idea must have been in the mind of Philo, who thinks of the soil from which the tree grew as the Logos ${ }^{1}$; and the last embodiment of this idea is the Tree of the Elements used by the alchemists. The most beautiful account is that in the Zohar III, fol. I I9-20. Reference is made to the conceptions of day and night, and their connection with the Tree of Life and the Tree of Death. At night-fall the Tree of Life soars up to heaven and its place is taken by the Tree of Death. At this time the soul must be commended to the Tree of Life. In another passage, ${ }^{2}$ however, the Tree of Knowledge is identified with the Tree of Death. "And she took of its fruit, as it is said, and pressed the grape out and gave it to him, and thereby brought death to the whole world. For in this tree was death and this is the tree which prevails in the night." Thus the Tree of Knowledge is here described as a vine, and as a Tree of Death.

We now turn to mediaeval representations, and it must be noted at the outset that the most important branch of art in which the imagination of the Jews found expression-the illuminated manuscripts-has suffered widespread destruction through the frequent migrations and plunderings of the owners, and that what remains has never been systematically described and collated; so that the material can be dealt with only in a fragmentary way. Yet we may establish several different types of representation of the Tree of Life, which probably depend on the popular tradition fixed in the first place by the Midrashes and then transmitted orally from generation to generation. Only one of the miniatures published below is free from Messianic eschatological symbolism. It is a miniature of the thirteenth century, and is a direct allusion to the account in Genesis II, 9, although it is isolated from the context. It is to be found on fol. 5 of the MS Hebr. 4 in the Bibliothèque Nationale in Paris (Pl. 56a). It is a huge Bible written in the characteristic German quadrate script with a marked inclination to the left-written on the 27th Ijar 1286, the work of one Isaac Ben Baruch who probably lived in Western Germany. The other miniatures in this MS are interesting from an artistic point of view because in addition to the characteristic French trend of the illuminations there are marked traces of influence from Bologna.

Four slender brightly coloured pillars are supported by a griffin, a lion, a peacock and an ostrich with necks intertwined and two beasts of prey with the front parts of their bodies joined. On these pillars rests a light architectural design consisting of shallow rounded arcades and turrets. This architecture forms a framework for a rectangular field on which the initial word b'rejschit is inscribed in large gilt letters. In the middle of the vignette on a half-blue and half-strawberry coloured ground spangled with white stars there is a tree with a green stem and brightly coloured leaves, blossoms and fruits. It might have been supposed that the illuminator intended to indicate a landscape connected in some way with the hunting-scenes represented between the spirals of an acanthus-tendril at
${ }^{1}$ R. Eisler, Weltenmantel und Himmelszelt, p. 575.
${ }^{2}$ Zoh. $3^{6-37}$ to Genesis III, 6. 
the base of the initial inscription. But this is not the case. It is the Tree of Life in the form of the Tree of the Seed. The stem is straight and the leaves, fruits and flowers are of different species. The careful execution of detail-small berries, acorns, flowers, grapes, ivy, lime- and oak-leavesshows the tendency of the illuminator, half in the Romanesque tradition, half under the new Gothic influence, to build up the miraculous tree as realistically as possible, using the botanical details with which he was familiar.

We find another conception of the Tree of Life in the miniature fol. I $22 \mathrm{~V}$ of MS Add. I 639 in the British Museum (Pl. 57a). It is carefully executed with body-colour on a gold ground. The date of it is 1278 and it is probably the work of a professional illuminator in Metz, who had before him the best examples of northern French early Gothic bookillumination. ${ }^{1}$ It is a collection of a number of Hebrew passages of liturgical and poetical character, and contains, apart from the text and independent of it, thirty-nine full-page illuminations of excellent workmanship. They form a complete Jewish Bible historiale, except that there is no historical order in it. The scenes follow one after the other in a vivid sequence; it has still to be seen whether the later binder was responsible for this disorder. Even though the pictorial forms are Gothic-French in character the iconography deviates at many points from the norm established in the Paris Christian Bibles of the same period. Thus, if we limit ourselves to the Messianic themes, we find (fols. $5^{1} 7,5^{18}, 5^{19}$ ) the monsters of the Creation and the Latter Days which we have seen in conjunction with the Tree of Life on monuments of late antiquity - beasts which are to give food to the righteous in the life hereafter - the Leviathan and the Behemoth, to which is added the giant bird $\mathrm{Ziz}$, the Çaena-Maergha of the Parsees. ${ }^{2}$ We shall look in vain among the mediaeval Christian monuments for analogous representations. The same is true of the miniature (fol. $122 \mathrm{v}$ ) which belongs to the same cycle of ideas. It is a picture of the promised Tree of Life intended as an illustration to Genesis III, 24: "And he placed at the east of the garden of Eden Cherubims, and a flaming sword which turned every way to keep the way of the Tree of Life". We see a fruit-laden orange-tree, planted on a hillock. In appearance the Tree of Life here approaches the tree in the Greek myth with the golden apples of the Hesperides. Four youthful winged cherubs in the corners of the rectangular field watch over the tree which occupies the whole central space from the lower edge to the top. Instead of the rotating sword of fire of the Genesis account, each angel holds a lance. The four slender draped figures bow with graceful balanced gesture, supported by the narrow shafts of their lances. To remove all suspicion the illuminator explained the nature of the scene in writing in the top left-hand margin and gave the name of the tree ez-ha-hajjim.

The next illustration ( $\mathrm{Pl} .56 \mathrm{~b})$ is of iconographic interest, though it is artistically of no significance and even childishly badly drawn. It is a

1 The MS is briefly described in G. Margoliouth, "An ancient Hebrew manuscript at the British Museum," 7. Q. R., XVII, I9o8, pp. I93-197.
2 Z. Ameisenowa, "Das messianische Gastmahl der Gerechten in einer hebräischen Bibel aus dem XII. Jahrhundert", $M G W \mathcal{J}$, I 935, pp. 409-422. 

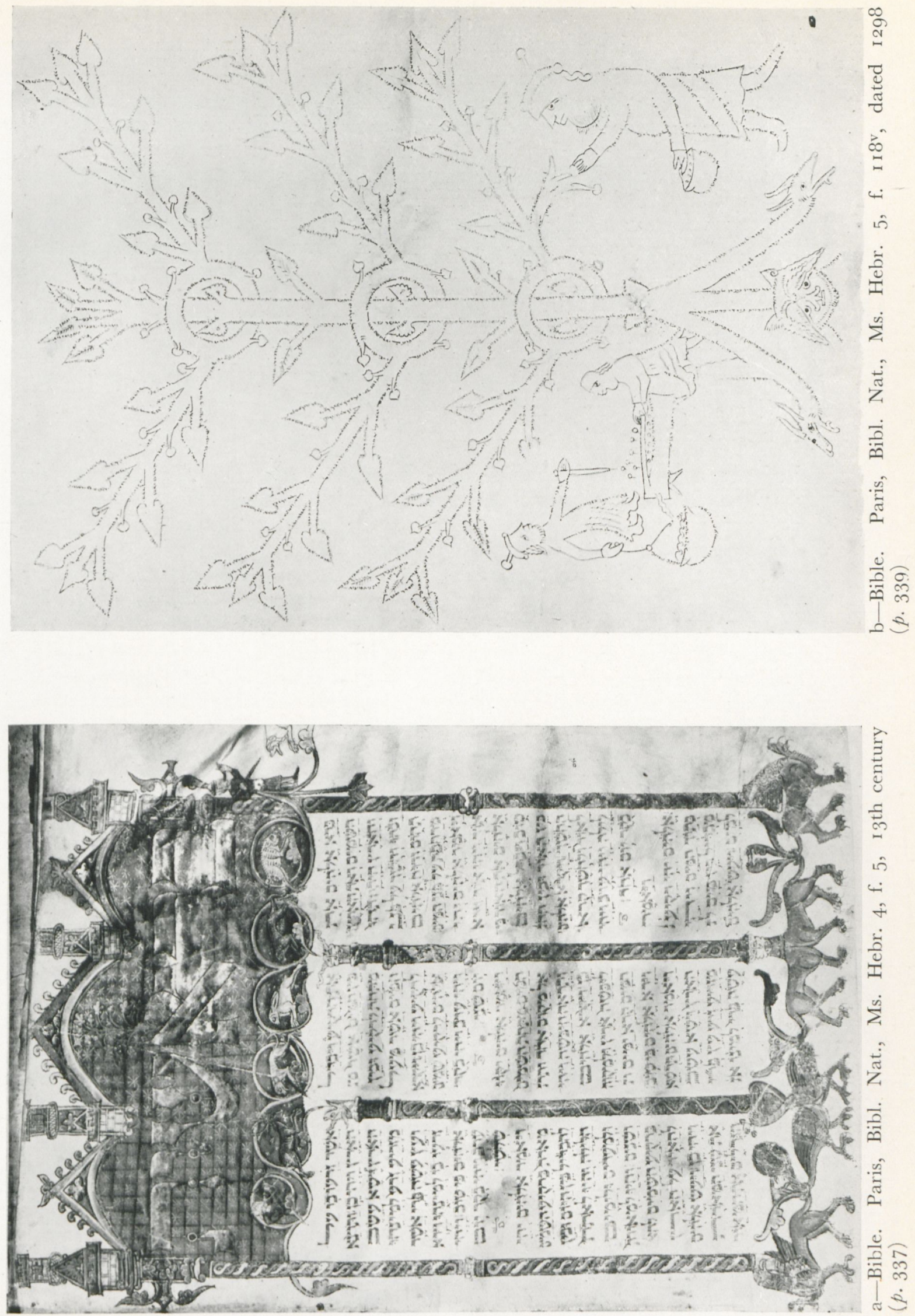
large drawing of the Tree of Life $(400 \times 300 \mathrm{~mm})$ composed of micrographic letters of the masoretic type, and occurs on fol. I I8v of the Hebrew Bible of I298, which is probably of German provenance (now MS Hebr. 5 of the Bibl. Nat. in Paris). ${ }^{1}$ Here we have an olive-tree with seven branches (corresponding to the branches of the candlestick) shown in diagram jutting off symetrically to left and right and bearing leaves and olives very simply conventionalised. The trunk of the tree passes through three rings from which the branches spring. The roots of the tree divide into three arms, each of which ends in the head of an animal with open jaws - a naive reference to the "springs of the waters" beneath the roots of the Tree of Life, here symbolised as gargoyles of the Romanesque type. A man in a Jewish hat on the right is gathering olives, another on the left is pressing out the oil in a primitive press and a third is collecting the oil in a round basin. This is not a representation of the symbol of the doctrine or of the source of light for the candlestick. It is a tradition known to the apocalyptic writers and continued in the Talmud, according to which the Tree of Life gave not only fruit but also oil which is used by the righteous in after-life and gives them immortality. ${ }^{2}$ Thus we have a graphic image of the old tradition which goes back to late antiquity and was current among the German Jews in the thirteenth century. This is a unique representation of it. Another extremely unusual miniature is found on fol. 23I of the MS Hebr. 48 in the Bibl. Nat. (Pl. 57b). This manuscript is a two-volume Bible written at the beginning of the fourteenth century probably in the West of Germany, partially illuminated when it was written, sold in $\mathrm{I} 482$ to Venice, where the illumination was completed in the sixteenth century. The vignette with the initial word w'eile belongs to the original illumination. It is a square field framed and divided into three variously coloured rectangular zones with white network ornamentation. In the lowest zone on a vermilion field a bluish-grey winged dragon with a fearsome horn on its forehead keeps guard over the Tree of Life, which is simply drawn in candelabra form with symmetrical branches and is of indeterminate species. The central zone is occupied by the gilt initial word on a lazuli ground. In the upper zone on a light crimson ground are two grey birds of prey, apparently eagles, represented in profile facing each other. Although the illuminator uses Gothic forms and colours imported into the West of Germany from France, this delicately executed miniature produces the same impression as many Jewish works of art of various epochs. The artist seems to aim at conventional flat treatment, at a decorative effect suggestive of tapestry designs - at the immobility befitting a hieratical subject. His chief concern is not the plastic modelling of things in space but the decorative construction of the whole composition on a flat plane, to include the imposing gilt initials. From a morphological point of view this miniature is a forerunner of the

1 Described by R. Wischnitzer, op. cit., p. 45 , as a miniature. It is taken to be a representation of the Tree of Life but is interpreted either as a symbol of the Thora or as a source of oil for the seven-branched candlestick represented on fol. I $18 \mathrm{r}$. This surely is a mistake. 2 Vita Adae et Evae, 36, Troje, op. cit., pp. 83-89. W. Bousset, Die Religion des Fudentums im neutestamentlichen Zeitalter, 1906, p. 556 . 
animal and bird vignettes in the Darmstadt Haggadah of about a century later; in the Darmstadt Haggadah also there is a Tree of Life and a Fountain of Life. ${ }^{1}$ But when we enquire into the iconographic sources we find that the illuminator borrowed from an illustration of the Physiologus. We have shown elsewhere that Jewish artists often drew inspiration from the Physiologus manuscripts and the Bestiaries so widely popular in mediaeval times. The precious Hebrew Bible of the thirteenth century of French origin (now in the Ossolineum in Lwów), for example, has a series of decorations taken from a French Bestiary among which there is a scene where sailors are chasing a siren. ${ }^{2}$ The tree guarded by a dragon is the Peridexion, the miraculous tree of the Physiologus which bears the sweetest of fruits. The dragon is lying in wait for the birds which nest in the top of the tree, but it fears the shadow of the tree and therefore seeks the opposite side. In the darkness the birds often lose their way and are devoured by the dragon. The Physiologus finds an allegory and points a moral to this fable in accordance with Christian theological doctrine. ${ }^{3}$ In the original text of the Greek Physiologus and in the Bestiaries the birds are indeed called doves in accordance with the biblical injunction "Be ye therefore wise as serpents and harmless as doves." 4 But in the Paris MS Hebr. 48 the illuminator had no intention of representing the Peridexion; he probably had in mind the paradisiac Tree of Life which was guarded by two cherubs in the form of eagles. Only the use of the dragon shows the dependence upon a Physiologus illustration. ${ }^{5}$

The three next pictures of the Tree of Life, although produced at different times and in different places, belong to one and the same set of ideas. The earliest is the miniature Pl. 57d of the Codex Ausst. 4 of the Stadtbibliothek in Frankfort, a Provençal Hebrew folio-Bible, the text of which dates from the beginning of the thirteenth century, whilst the illuminations (on parchment leaves added subsequently) date from about the year I $300 .^{6}$

On fol. 25 filling the whole page is a golden vine with reddish-blue and white grapes on a red squared and netted ground. The twistings of the stem are developed in double spirals symmetrically on both sides of the central stem which passes through eight rings. The spirals are evenly distributed over the whole framed field and there is no attempt at perspective recession. The effect of the miniature is that of a tapestry or a piece of embroidery. There is no doubt that we have here a Tree of Life in the form of a grape-vine.

No early monuments support Eisler's categorical assertion that the Tree of Life of the Hebrews was thought of in the first place as a vine and that the Water of Life was wine. ${ }^{7}$ Nor does the discussion concerning the vine

1 Die Darmstädter Pessach-Haggadah, ed. by A. Freimann, B. Italiener, A. L. Meyer, Leipzig, 1927, fol. 47 .

2 Cf. Z. Ameisenowa, "Bestiary in a Hebrew Bible of the XIIIth century," (in Polish), Miesięcznik Żydowski, Warsaw, 1933.

${ }^{3}$ F. Lauchert, Geschichte des Physiologus, Strasbourg, r889.

${ }^{4}$ Mat. X, 16.
5 Cf. W. Molsdorf, Führer durch den symbolischen Bilderkreis, Leipzig, 1920, p. 105.

${ }_{6}$ R. Schilling and G. Swarzenski, Die illuminierten Handschriften . . . im Frankfurter Besitz, Frankfort, 1930, no. 48.

7 R. Eisler, "Orphisch-dyonis. Mysteriengedanken in der christlichen Antike," Vorträge der Bibl. Warburg, Vol. II, Part 2, Leipzig-Berlin, 1925, pp. 147-48. Louis 
in the Talmud refer to the Tree of Life, as Eisler supposes; - the reference is to the Tree of Knowledge. Yet besides the date- and olive-trees of life the Jews must also have had vine-trees of life, for we have the evidence of later mediaeval monuments. On early Christian sepulchres, especially those of Syro-Mesopotamian origin or those which come from Ravenna or the South of France and were carved under Syro-Mesopotamian influence, the vine was a very popular ornament and nobody doubts its symbolical significance. $^{1}$ But whether the representations on the sarcophagi from Ravenna in which the cross, the monogram of Christ, or the Fountain of Life is associated with a grape-vine and birds pecking at it can be related to the Tree of Life is a question which remains unanswered. ${ }^{2}$ At all events there are Jewish representations of a vine as Tree of Life the symbolical meaning of which is beyond doubt. There is for example the tympanum of the main gate of the Altneu synagogue in Prague of the sixties of the fourteenth century where the vine grows upon a hillock from which conventional jets of water are flowing, i.e. "a tree by the spring of the water." Thus we may assume that the vine in the Frankfurt Bible was meant to be a Tree of Life. And this assumption is supported by other evidence. Apart from the vine the other leaves bound on at the beginning of the Frankfort Bible contain a shield of the High Priest, vessels of the Temple, the seven-branched candlestick and the Ark of the Covenant.

The same themes with minor variations were chosen by two other illuminators for MS No. 12 in the library of the Jewish Theological Seminary in Breslau and MS Hebr. 3I in the Bibl. Nat. in Paris. The Breslau Bible comes from the Saraval collection and was probably written and illuminated in Italy in the second half of the fourteenth century. Four parchment leaves bound on the front represent the seven-branched candlestick, a goblet, the Tables of the Law, the vessels of the Temple, a wine or oil jar, Schofar and trumpets. On fol. $4 \mathrm{v}$ there is a green tree of indeterminate species with a split trunk. ${ }^{3}$ Finally MS Hebr. $3^{\text {I }}$ in the Bibl. Nat. is a small folio Bible beautifully bound in pressed leather ornamented with stars, written in Saragossa in I404 by Hayjjim ben Saul, called Vidal Satori. In this case also the illuminated pages are bound to the front of the MS and have no direct relation to the Bible texts. On fol. Iv we have a full-page illumination; on a ground half-red half-lapis lazuli is the golden candlestick in conventionalised form. Fol. $2 \mathrm{r}$ is blank. On fol. $2 \mathrm{v}$ are the following ceremonial objects : the table for the

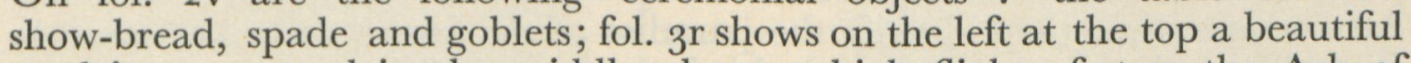
mudejar vase, and in the middle above a high flight of steps the Ark of the Covenant with the Table of the Law fastened to two posts together with knives and spoons.

The most interesting of the miniatures, unfortunately rubbed like the rest, fills the whole of fol. $4 \mathrm{r}$ (Pl. 57c). On a ground half-red and half-blue

Ginzberg, Die Haggada bei den Kirchenvätern, Berlin, I 900 , pp. 36-42.

${ }^{1}$ C.-M. Kaufmann, Handbuch der christlichen Archäologie, 3rd ed., Paderborn, I922, p. 293.

2 Cf. A. Thomas, Die Darstellungen Christi in der Kelter, Düsseldorf, I936, pp. I 70-18o. 3 Reproduced in Enc. Judaica, Vol. IV, cols. 543-544; the remaining folios in Bericht des füdischen Museums in Breslau, (without heading), r931, pl. 4 . 
is a tree, growing on a hillock of piled-up stones; the tree was originally green but is now of a blackish tone. The trunk is split into two large branches, and the twigs are covered with trilobate pointed leaves. On both sides of the tree two large birds are hovering, represented in profile facing each other. This time they are not eagles but birds of paradise, as can be seen from the three long-fringed tail-feathers. Like the eagles in MS Hebr. Paris 48 (Pl. 57b) they represent the angels guarding the Tree of Life. As was mentioned above, the Jewish painters of mediaeval times often portrayed angels in the form of birds: in a richly illuminated Bible of the fourteenth century, now in Cracow, the angel who prevents Abraham from carrying out the sacrifice of Isaac has an eagle's head, and in the same manuscript the cherubs guarding the Ark of the Covenant are birds with human heads. ${ }^{1}$

The assumption that the miniature of this Paris MS represents the Tree of Life is confirmed by the two hovering birds of paradise and also by the text from Zech. XIV, 4 which runs round three sides of the picture : "And his feet shall stand in that day upon the mount of Olives, which is before Jerusalem on the East, and the mount of Olives shall cleave in the midst thereof toward the East and toward the West." The eschatological explanation of this passage is to be found in the Pesikta rabbati. ${ }^{2}$ It tells of the righteous who have died during the dispersion. The Almighty will make caverns in the earth and he will cause the dead to wander till they come to the Mount of Olives which is near Jerusalem. God will appear at this place on the Day of Judgment and the mountain will open and all the dead will arise, as it is written in Zech. XIV, 4 .

This representation and text furnish the key for the true understanding of the illuminations in the three last-mentioned manuscripts. They are not mere illustrations to the text of Genesis II, 9 and Exodus XXV dealing with the Tree of Life and the building of the Tabernacle. They are the embodiment of sets of ideas purely eschatological and apocalyptic. That the Tree of Life has its place among them is clearly proved by the wording in the miniature of the Paris MS Hebr. 31. But the representations of the candlestick and the vessels of the Temple are also related to the Day of Judgment, the resurrection of the dead and the coming of the heavenly Jerusalem. Ezekiel (XLVII, 7-I2) prophesies that the Tree of Life shall be planted near the house of the Lord on the Day of Judgment. The apocalyptic writers have visions of the restoration of the Temple and the resumption of sacrifice. At the same time they identify the paradise of the future with the heavenly Jerusalem. And connected with this is the legend of the finding of the lost vessels of the Temple. ${ }^{3}$ According to the rabbinical sources quoted by Bousset, the vessels of the Temple, which disappeared after the Babylonian captivity shall come to light again in the Messianic age when the Temple also is restored. Before the destruction of Solomon's Temple the vessels are supposed to have been buried by King Josias (or according to others by

1 Cf. Z. Ameisenowa, Biblja hebrajska z. XIV. wieku w Krakowie $i$ jej dekoracja malarska, Cracow, 1929, pls. I and III. Philo speaks explicitly of the Cherubim as birds. Vita Mos.
III, 8. Ed. Cohn-Wendland, IV, p. 223.

${ }^{2}$ Fol. 55, c. 1, 2. Ed. Friedmann I47 a.

${ }^{3}$ W. Bousset, Die Religion des Judentums im neutestamentlichen Zeitalter, I906, p. $274 \mathrm{f}$. 


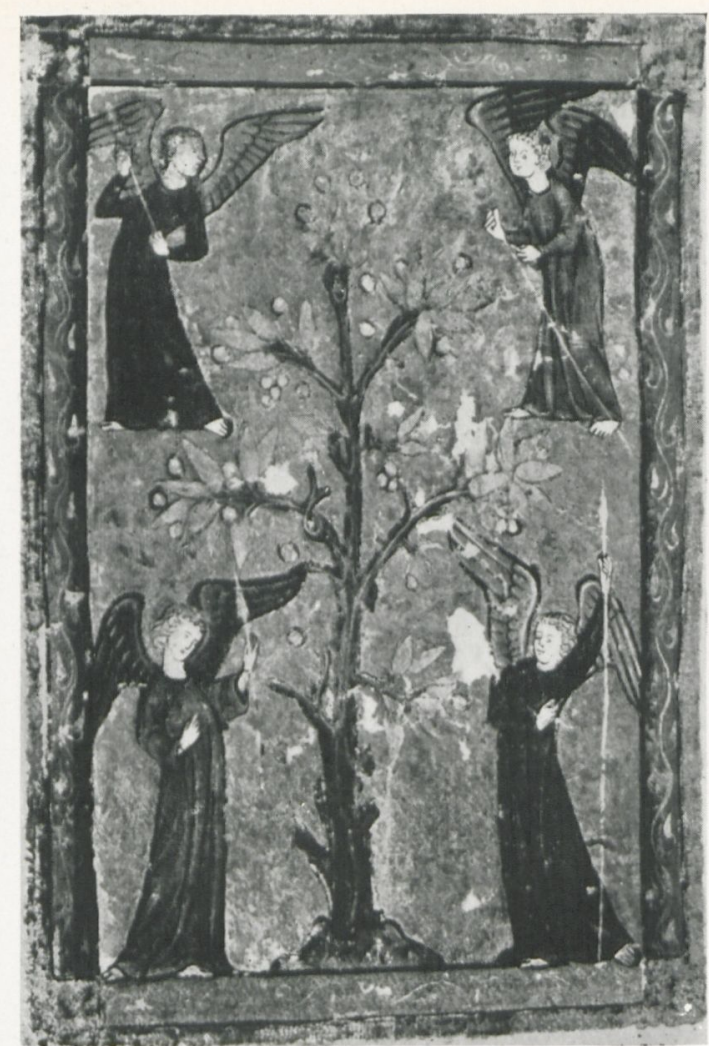

a-Hebrew Ms. British Museum, Add. I 639, f. I $22^{v}$, dated I $278\left(p .33^{8}\right)$

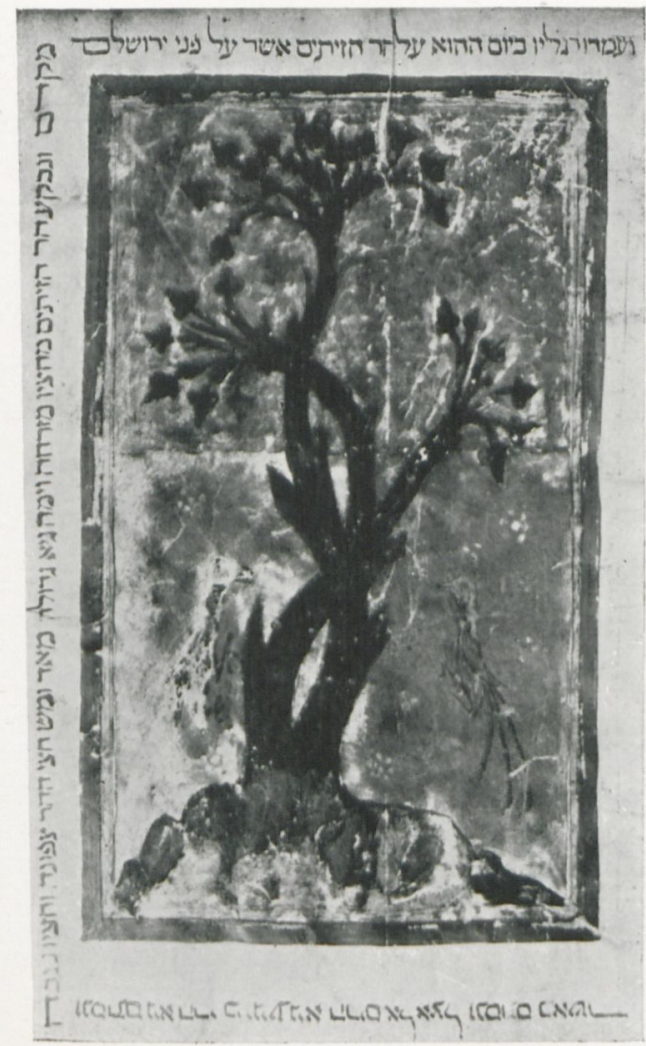

c-Bible. Paris, Bibl. Nat., Ms. Hebr. 3I, f. $4^{\mathrm{v}}$, dated $\mathrm{I} 4 \mathrm{O} 4\left(\right.$ p. $\left.34^{2}\right)$

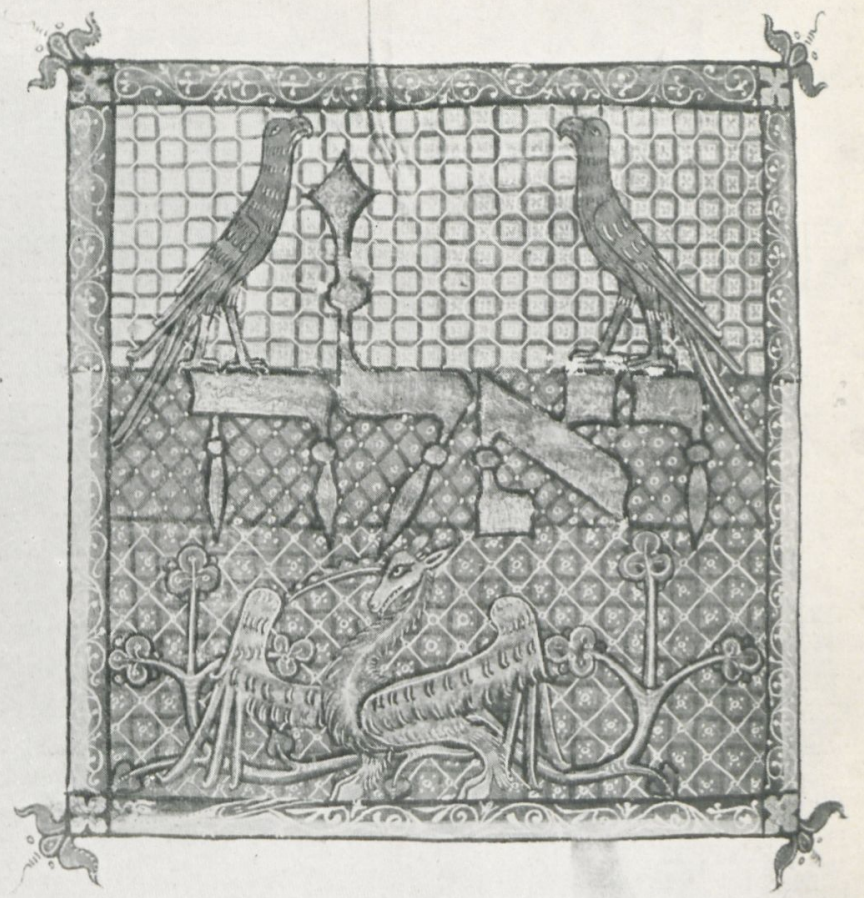

b-Bible. Paris, Bibl. Nat., Ms. Hebr. 48, f. 23I, I $4^{\text {th }}$ century $(p .339)$

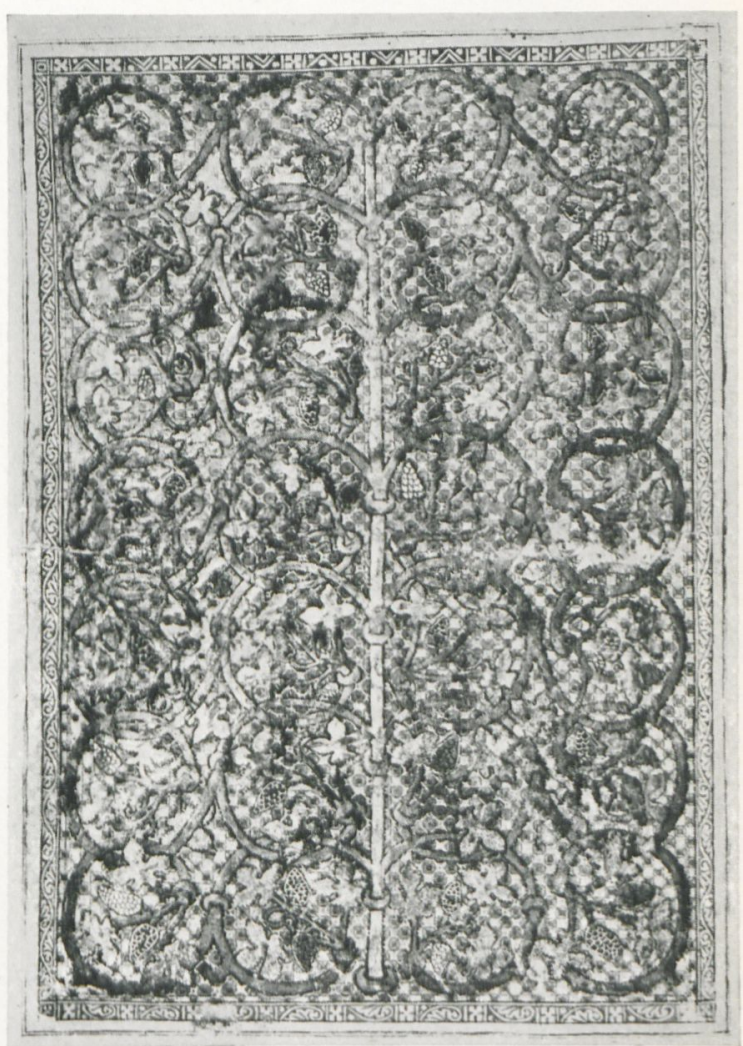

d-Bible. Frankfort, Stadtbibl., Cod. Ausst. 4, f. 25 , c. $1300(p .340)$ 

Jeremiah or Baruch) in some secret place where they are to await the coming of the Messiah. People cherished the hope that they would come to light in some miraculous way in the last days. With this historical interpretation the analogous series of illuminations in the Frankfort, Breslau and Paris Bibles and in all similar ones which may be found become intelligible.

In their time-honoured daily prayers pious Jews find expression for their Messianic hopes. In the Habinenu they pray for the restoration of the Temple and of divine service in it, and in the prayers for the dead they make lengthy petition for the renewal of the world, the revival of the dead, the building of Jerusalem and the Temple, the coming of the Messiah and of God's kingdom upon earth. In the same way men of artistic taste in the thirteenth, fourteenth and fifteenth centuries, gave their orders to the illuminators so that their Messianic hope might acquire plastic form. These miniatures, constantly before the eyes of the pious as they studied their Bible day by day, were a tangible symbolic rendering of the phrases upon their lips : I hope for the coming of the kingdom of God, for the re-building of the Temple in all its ancient glory, for the coming of the Messiah and for life everlasting. It was a fervent Messianic prayera confession of faith in pictures.

Is this series of miniatures something new to the Middle Ages, or is it a tradition maintained from much earlier times? This is a question which cannot be answered with certainty. But we are tempted to think of an old tradition. For among other manuscripts the badly-damaged Bible codex which is now in Leningrad (MS Hebr. II, I 7), the work of Salomon Halevi bar Buya in the year 930, contains a miniature showing the resplendent golden vessels of the Temple. And the Christian Topography of the sixthcentury Alexandrian navigator, merchant and monk, Kosmas Indikopleustes, a tract based on the Bible, full of Jewish speculation and subordinating everything to the one thought of God, shows even in illustrated copies of the ninth and tenth centuries the candlestick and vessels of the Temple and also pictures of the Tree of Life with birds on either side. ${ }^{1}$ But there is also a Jewish monument of late antiquity which clearly shows that there must have been a series of Jewish pictures with eschatological symbolism of the same kind as that in our three manuscripts. This is not at all surprising in view of the abundance of apocalyptic literature of the time.

In the synagogue of Beth Alpha discovered by Sukenik ${ }^{2}$ there is a large mosaic floor and in the front part of this are a number of objects of which all but two have been correctly interpreted by Sukenik. The mosaic dates from the time of Justinian I $\left(5^{1} 7-528\right)$; though of crude workmanship it is of the greatest importance from the iconographic point of view. It represents three main themes. Besides the sacrifice of Isaac and the Zodiac, the Ark of the Law (Aron ha-Qodesch) is shown, guarded by two cherubs in the form of birds and surrounded by conventional objects of ritual and religious symbols, all relating to the Temple. (Pl. 55e). Between the folds of the curtain, which is drawn back, we see two seven-branched candlesticks

${ }^{1}$ Reproduced in C. Stornaiolo, Le miniature della topografia cristiana di Cosma Indicopleuste, Milan, Igoo.
2 E. L. Sukenik, The ancient Synagogue of Beth Alpha, Jerusalem-London, 1932, p. 34, pl. VIII. 
(repeated for the sake of symmetry) two lions in side-view, two Ethrogs, Lulabs and Schofars. But I cannot agree with Sukenik when he says (p. 34): "The naive drawing on the right hand side of the Menorah of a tree with a bird perched on it and the branch to the left of the Menorah, are obviously only to be regarded as decorations in the current fashion filling the blank space of the panel." The flowering twig and the tree with the bird in Beth Alpha are not mere arbitrary ornament. By strict analogy with the series of miniatures from mediaeval Hebrew Bibles which we have just interpreted, we may certainly assume that the blossoming twig is Aaron's staff and the tree with the bird on top is nothing but the Messianic Tree of Life in the midst of the future Temple. It is true that the motives which are thrown together in the mosaic of Beth Alpha are later distributed over several miniatures; but the same eschatological symbolism is recognisable.

A miniature in the prayer-book of the synagogue at Wolpa in Poland, ${ }^{1}$ where a unicorn and a lion guard the Tree of Life, shows that the old tradition of the Tree in book-illustration had not died out even in the baroque age.

At this point we should conclude the investigation. As such a small number of examples have been adequately described and reproduced, it would be unsafe to discuss the occurrence of the Tree of Life on Jewish frescoes and works of applied arts in the baroque, rococo and Empire. We shall therefore limit ourselves to two examples of Jewish folk-art, chosen to illustrate the persistence of the Tree of Life symbol even down to our own times. These are firstly the tomb-stones and secondly the pieces of paper cut out by school-boys in the little Polish towns and pasted on windows or framed in honour of certain festivals. A Polish scholar recently pointed out that the most frequent decorative motive on eastern Jewish graves in the baroque period was the Tree of Life in its most diverse types and variants, sometimes combined with the candlestick. ${ }^{2}$ Pl. $55 \mathrm{C}$ shows a tomb dated I 770 from the old Jewish cemetry of Źockiew (East Poland) in which the Tree of Life is characterised by huge clusters of fruit. There has thus been no fundamental change since late antiquity; only the formal conventional treatment of the motive has been modified. The Tree of Life, as a symbol of Paradise and the food of the righteous, was the same among the Jews in the days of the apocalyptic writers, in the Middle Ages and in the life-time of Voltaire.

The same frequency of occurrence of the Tree of Life was noted by Giza Fraenkel in an article on Jewish paper-cuttings. ${ }^{3}$ There might be room for doubt as to the symbolical meaning of these trees in late works of folk-art in the nineteenth century; but such doubts are dispelled by a remarkably instructive cutting. (Pl. 55 d). It comes from Jarczow in the Lublin district of Poland and was published by Regina Lilientalowa. ${ }^{4}$ On this piece of paper, cut out and coloured, the whole popular cosmology of the Jews was represented. At top and bottom, between two pierced strips are twelve round medallions with the signs of the Zodiac inside, which

1 M. Grunwald, in Mitteilungen für die jüdische Volkskunde, I904, p. 8.

2 H. Ciesla, "Ornament nagrobnych kamieni zydowskich i jego symbolika." Spraw. Tow. Nauk., Lwow, 1935, XV, pp. 4-7.
3 G. Fraenkel, "Wycinanka żydowska w Polsce," Lud, r929, pp. 39-57.

4 R. Lilientalowa, Swięta żydowskie w przeszltosci $i$ teraźniejszości. T. I. Kraków, I908, fig. V. 
start with the Ram and end with the Fishes (reading from right to left, like the Hebrew script). The central oblong panel in the design is in strong contrast to the dark ground. In the middle, between two rather clumsy tendrils, which keep the whole thing together, we see the globe. At the North Pole grows the cosmic Tree of Life, with a bird on each side. It reaches from the earth to the sky which is spanned by a serpent biting its own tail-another embodiment of the Leviathan. On the left is the disc of the sun and on the right the half-moon. The village school-boy who made this cut-out for Schewuoth or the Sukkot, had probably heard his master repeat a text from the mystic book of Rasiel or a similar one which mentions Teli, the snake, identical with the Leviathan. To Teli the signs of the Zodiac are attached; he courses through the air and sometimes, as we have seen, bites its own tail. ${ }^{1}$ It is very typical that astronomical, cosmological and Messianic motives should be combined; for that belongs to the nature of both feasts for which the design was cut out.

Thus the legend of the cosmic tree cannot have died out among the eastern Jews in the nineteenth century, if round about I9oo, in an advanced industrial age, such representations as this paper-cutting could be produced. The myth of the World-Tree, conceived in pre-historic times by the Chaldæans, returned after long and distant wanderings to one of the sources from which it came-the imagination of the Jewish people-and so stirred it to produce once more these naive but delightful children's works, in which we catch a faint glimpse of fabulous cosmogonies and a millennium of human dreams.

Translated by W. F. Mainland

1 R. Eisler, Weltenmantel und Himmelszelt, p. 389, note 2. 